\title{
Paleoseismology of the Yangsan Fault, southeastern part of the Korean Peninsula
}

\author{
Jai Bok Kyung \\ Department of Earth Sciences, Korea National University of Education, Kangnae, Cheongwon, Korea
}

\begin{abstract}
The NNE-trending Yangsan Fault (YSF) is the most prominent fault in the southeastern part of the Korean Peninsula and has a continuous trace about $200 \mathrm{~km}$ long. Activity on this fault was recently investigated using aerial photographs, topographic analysis, and trenching. The geomorphologic evidence of Late Quaternary faulting is clearly recognized on both the northern (Yugyeri and Tosung-ri areas) and southern parts (Eonyang to Tongdosa area) of the fault. The main YSF is marked by a zone of shattered rock that is tens of meters wide and zone of fault gouge. During the Late Quaternary, right-lateral movement occurred mainly on the southern part, as shown by lowangle striations on the fault plane, elongation of deformation features in the fault gouge. The estimated vertical slip rate is about $0.02-0.07 \mathrm{~mm} / \mathrm{yr}$, and the lateral slip rate may be several times larger than the vertical rate. The most recent event occurred prior to deposition of Holocene alluvium. In the northern part, the fault locally changes trend to almost N-S, dips to the east and has reverse movement. The average vertical slip rate is estimated less than $0.1 \mathrm{~mm} / \mathrm{yr}$. The most recent event probably occurred after 1314 cal. years BP (A.D. 536).
\end{abstract}

Key words Yangsan Fault (YSF) - Korean Peninsula-averge slip rate - most recent event

\section{Introduction}

The level of seismicity in the Korean Peninsula is lower than that in neighboring parts of Northeastern China and Japan, but major damaging earthquakes have occurred in the peninsula during past 2000 years. Many of these earthquakes occurred in the Kyongju-Ulsan areas in the southeastern part of the Korean Peninsula (fig. 1). Historical records describe approximately ten damaging earthquakes in Kyongju-Ulsan area, some of which have caused fatalities and produced liquefaction.

Some of the earthquakes destroyed houses, created ground fissures, surface depressions, and

Mailing address: Dr. Jai Bok Kyung, Department of Earth Sciences, Korea National University of Education, Kangnae, Cheongwon, Chungbuk 363-791, Korea; e-mail: jbkyung@knue.ac.kr landslides, and caused liquefaction and sand blows. Eight of these large historical earthquakes occurred in and around the Kyongju area (A.D. 34, 100, 123, 304, 471, 510, 630, 779) (Lee, 1998). In particular, the Kyongju earthquake in A.D. 779 caused great damage, killed approximately 100 people, and is described in the historical literature 'Samguksaki'. The greatest earthquake (MMI X) in the Korean Peninsula occurred in the Ulsan area in 1643 (Lee, 1998), had a large felt area, triggered a tsunami, caused liquefaction along the coast, and destroyed some beacon lighthouses and castel.

Faults that could have caused these earthquakes include the NNE-SSW-trending Yangsan Fault and NNW-SSE trending Ulsan Fault (fig. 2). Of these two structures, the YSF has a strong linear expression and is continuously traceable for about $200 \mathrm{~km}$ (Yoon and Kim, 1990). The surface expression of the YSF is marked by a fault-controlled valley containing wide, NNESSW shatter zones, and sub-horizontal striations (Reedman and Um, 1975). The fault plane is 


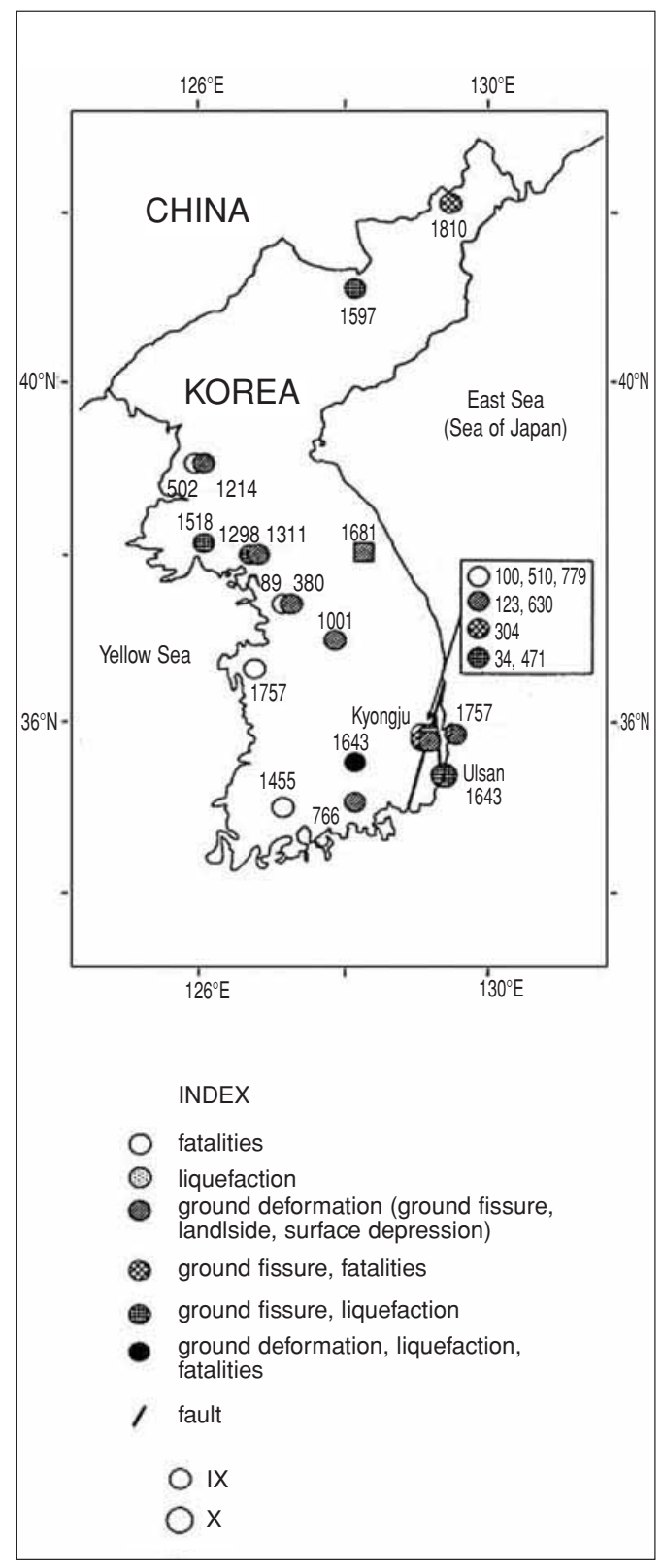

Fig. 1. Epicenters of large historical earthquakes (MMI equal to or greater than IX) which caused destructive damage in the Korean Peninsula from A.D. 27 to 2002 . The number in the figure represents the occurrence time (in years) of earthquake. almost vertical based on exposures in outcrops and geophysical data (e.g., Kim and Lee, 1988).

This study clarifies the history of the Late Quaternary movement on the YSF based on geomorphological studies, topographic mapping, and trenching. The study concentrated on two sites, one on the northern part of the fault at Yugye-ri area, and one on the southern part in the Eonyang to Tongdo-sa areas ( $\mathrm{Tn}$ and Ts in fig. 2).

\section{General tectonic setting}

The Korean Peninsula is part of the Amuria plate and is an important link between the continental blocks of North and South China and the island arcs of Japan. Major orogenic events in the Korean Peninsula occurred mainly in Late Paleozoic and Mesozoic time (e.g., Reedman and Um, 1975; Lee, 1987; Kim, 1996; Ree et al., 1996). In Late Permian to Early Triassic time, the Songrim orogeny produced strong deformation and metamorphism, and compressional deformation occurred again in the Early to Late Jurassic (Daebo event). Dextral ductile shearing associated with thrusting and folding continued in the mid-southern Korean Peninsula due to northwestward subduction of the Izanagi plate under the Asian continent (Maruyama et al., 1997; Chough et al., 2000). In Cretaceous time, the northward subduction of Izanagi plate formed strike-slip basins and the emplacement of volcanic and granitic rocks (Chough et al., 2000). Non-marine sedimentary rocks in these basins and volcanic rocks are mainly present in the southeastern part of the peninsula (Kyongsang Basin) (Chun and Chough, 1992). Figure 2 shows the general geology of the eastern part of the Kyongsang Basin. In Tertiary time, the southeastern margin of the Korean Peninsula experienced back-arc opening, resulting in deposition of Tertiary rocks in and around Pohang (Pohang Basin) in association with back-arc opening in the East Sea (Sea of Japan) (Chough et al., 1990; Yoon and Chough, 1995).

No prominent tectonic movements occurred during the Quaternary except for some isolated volcanic events. However, evidence of uniform uplift exists for much of the southern half of the 


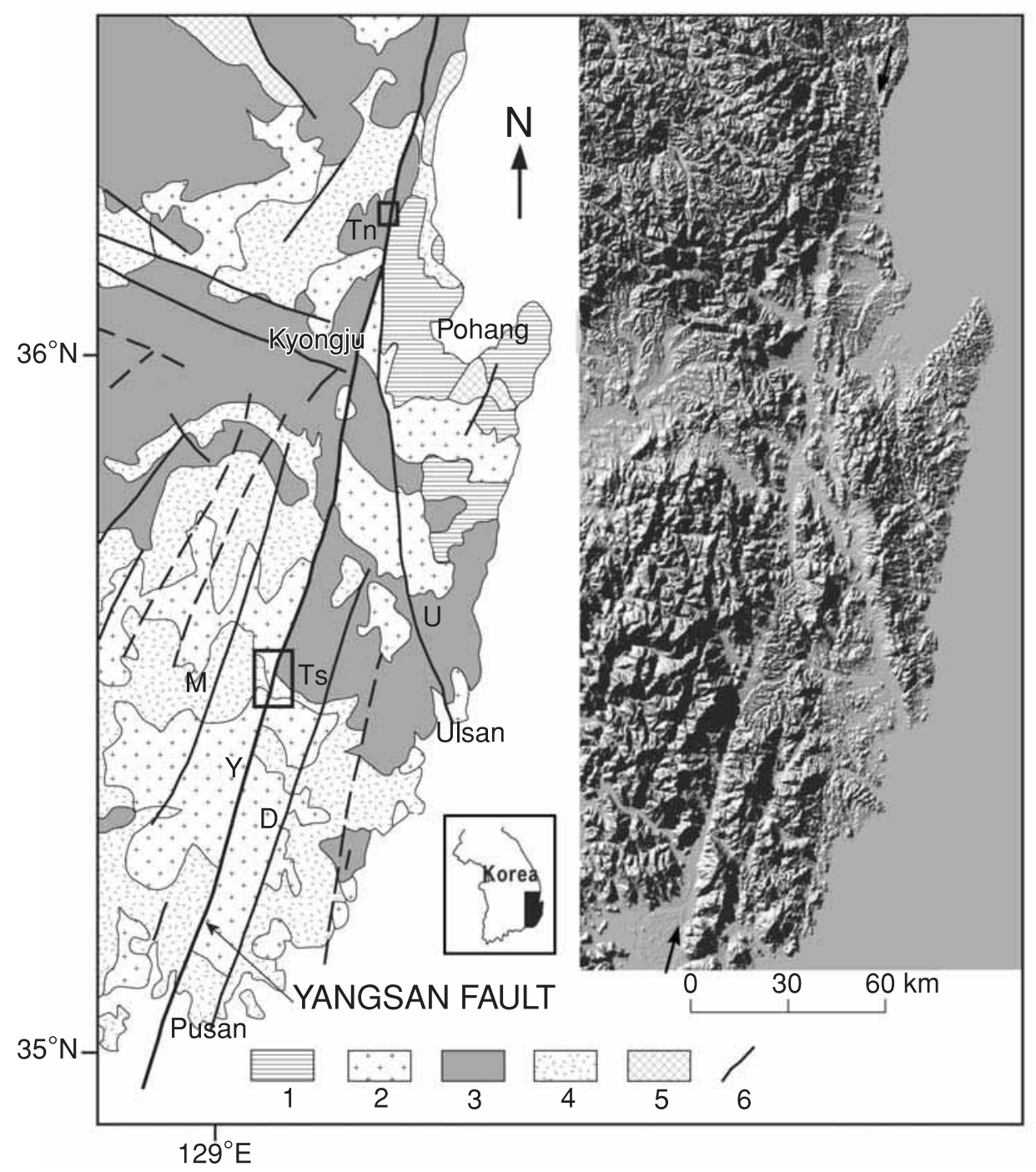

Fig. 2. Geological map (after Korea Institute of Energy and Resources, 1981) and the Yangsan Fault System in the shaded relief map of southeastern part of the Korean Peninsula. 1 - Tertiary basin deposits; 2 - Late Cretaceous to Early Tertiary igneous rocks; 3 - Late Mesozoic Kyongsang Basin deposits; 4 - Late Mesozoic Yucheon volcanics; 5 - Tertiary volcanics; 6 - Fault; M - Moryang Fault; Y - Yangsan Fault; D - Dongrae Fault; I - Ilgwang Fault; U - Ulsan Fault. Tn and Ts indicates the sites in the northern (Yugye-ri) and southern sectors (Eonyang to Tongdo-sa), respectively.

Korean Peninsula (Oh and Choi, 2001). Uplifted marine terraces are developed along the eastern coast (e.g., Oh, 1981; Choi, 1997, 2001; $\mathrm{Oh}$ and Choi, 2001). The average uplift rate of the eastern coast is estimated to be about $0.1 \mathrm{~m} / \mathrm{ka}$ since the last glacial culmination (oxygen isotope stage 5e) (Choi, 2001). Some faults, such as the Yangsan and Ulsan faults (fig. 2) 
were active in the Late Quaternary, even though their slip rates are estimated to be less than $0.1 \mathrm{~m} / \mathrm{ka}$ (Okada et al., 1994; Kyung et al., 1999a,b; Kyung and Im, 2001; Okada, 2001).

\section{Yangsan Fault System}

The Yangsan Fault System consists of several faults, including the Moryang Fault, the Tongrae Fault, the Ilkwang Fault and the Ulsan Fault (fig. 2). The YSF is one of the faults in the fault system and is a prominent dextral, strikeslip fault that has a clear, linear topographic expression for about $200 \mathrm{~km}$. It consists of two or three closely spaced, sub-parallel faults. The width of the fault zone varies in a regular, cyclical patterns every $25-35 \mathrm{~km}$ along strike (Chang, 2001). Along the northern part of the fault zone, its maximum width is about $5 \mathrm{~km}$ and along the southern part, the maximum width is about $6 \mathrm{~km}$. The significance of these regular changes in fault zone width are not known.

The YSF contains evidence of multiple deformation events through geologic time. Initial movement on the YSF probably occurred after $45 \mathrm{Ma}$ (Eocene) based on radiometric dating of volcanic rocks along the northern part of the fault (Chang et al., 1990). Paleo-stress analysis (Chae and Chang, 1994; Chang and Chang, 1998; Chang, 2001) indicates that movement on the YSF has been right-lateral strike-slip caused by NE-SW compression since Eocene time, including during its most active period in the Late Miocene. Later, the sense of movement changed to left-lateral under a NW-SE compressional stress regime at the end of the Miocene. In the Pliocene, N-S compression affected the fault, and in the Quaternary, the fault was reactivated by a right-lateral strike-slip movement in an E-W to ENE-WSW compressional stress regime. This is the present stress regime in the Korean Peninsula (Jun, 1991).

The total amount of dextral displacement on the fault is estimated to be about $35 \mathrm{~km}$ in the north (Chang et al., 1990) and about $25 \mathrm{~km}$ in the south, most of which occurred between 14 and $42 \mathrm{Ma}$ (Reedman and Um, 1975; Choi and Park, 1985).
To document the fault's Quaternary history, it is necessary to quantify the deformation of Quaternary deposits, but Quaternary deposits are not abundant or widespread on the Korean Peninsula. Locally, Quaternary deposits are present along the YSF, although these are largely restricted to small streams and valleys. We have studied these deposits at several sites to clarify the Late Quaternary faulting history of the Yangsan Fault (Okada et al., 1994; Kyung et al., 1999a,b; Kyung and Chang, 2001).

\subsection{Northern part of the YSF (Tn in fig. 2)}

In the Yugye-ri area on the northern part of the YSF (fig. 2), fluvial terraces along the Seojeong stream can be divided into four levels: Qt1, Qt2, Qt3 and Qt4 (fig. 3.). Here, Qa indicates the deposits of undifferentiated alluvium of the latest Pleistocene to Holocene. The fault was exposed in two excavations during construction of a dam. In this area, terrace Qt2 is cut by several fault splays, which are buried with alluvial deposits (unsorted pebble to boulder gravel). A fault scarp on the Qt2 terrace has a down-to-the-west vertical displacement of about $1.5 \mathrm{~m}$ (fig. 3; profile $\mathrm{d}-\mathrm{d}^{\prime}$ and $\mathrm{e}-\mathrm{e}^{\prime}$ ). The fault plane forms the boundary between alluvial deposits on the west and Cretaceous sedimentary rocks on the east. It strikes almost $\mathrm{N}-\mathrm{S}$, dips to the east about $45^{\circ}$, and reverse-slip striations plunging about $40^{\circ} \mathrm{E}$ with hanging wall up-tothe west, resulting in right-lateral reverse movement. The fault has a gouge zone that is as wide as $1 \mathrm{~m}$ and a cataclastic zone several meters wide.

A trench at site A (fig. 3) exposed, alluvium consisting of unweathered pebble to boulder gravel with silty lenses (fig. 4). This alluvium was strongly deformed and overturned near the fault zone. The long axis of the slender gravel clasts near the gouge zone has been rotated and dips to the east, sub-parallel to the fault plane. Charcoal in silty sediments in the gravel yielded calibrated radiocarbon ages of 7182 (SNU 99-136) years BP, 11230 (SNU 99-135) years $\mathrm{BP}$, and $25900 \pm 730$ (SNU 99-118) years BP (table I) from the upper to the lower parts of the gravel. A humic layer in the lower of the terrace 


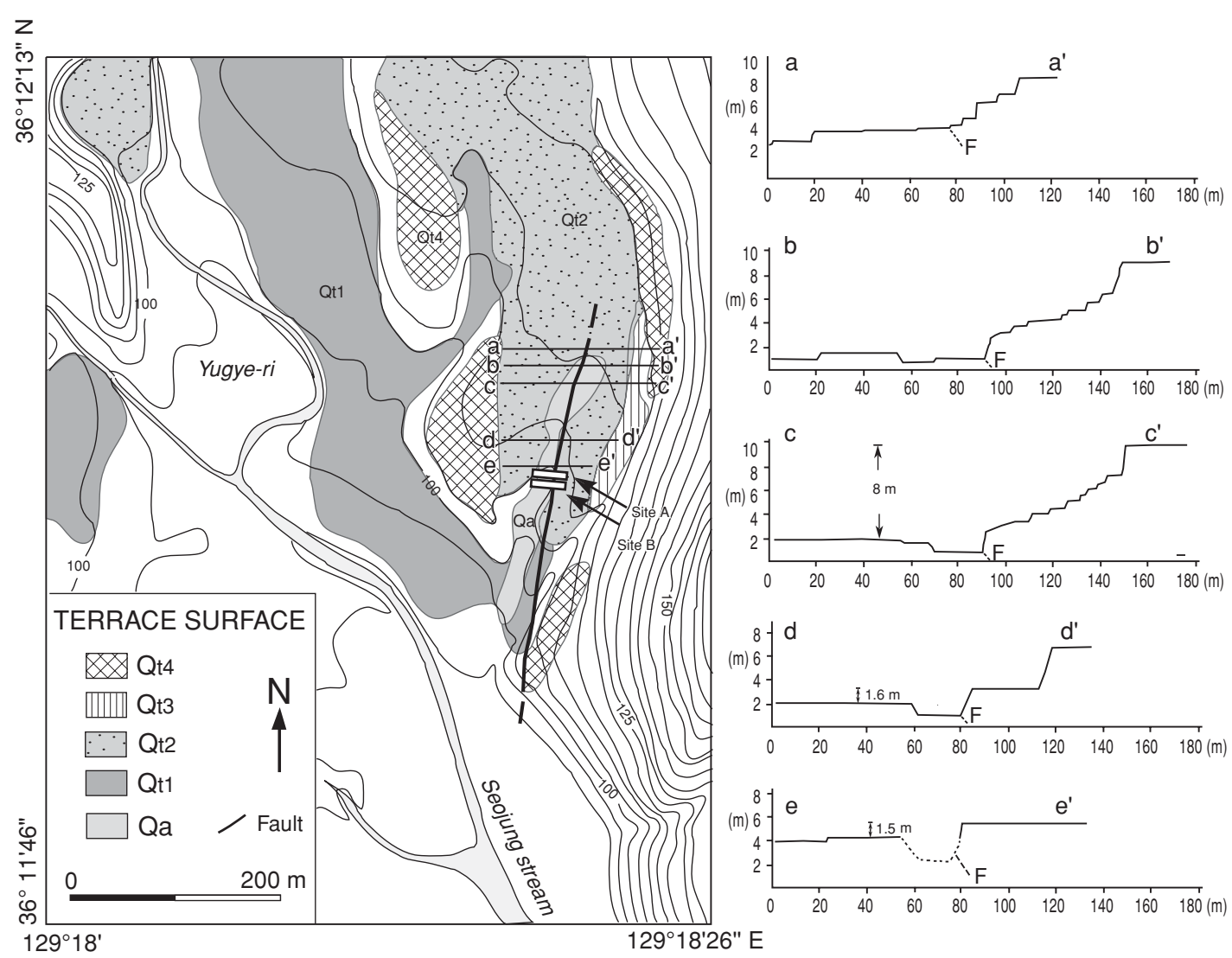

Fig. 3. Geomorphic map around the Yungye-ri area and topographic profiles across the YSF. A and B are the locations of excavations across fault. The lines from a-a' to e-e' indicate topographic profiles.

Table I. $\mathrm{C}^{14}$ dating result in the northern part of the YSF.

\begin{tabular}{lcccc}
\hline \hline Sample n. & Lab. $\mathrm{n}$. & $\begin{array}{c}\text { Radiometric } \\
\text { age }\end{array}$ & $\begin{array}{c}\text { Calibrated age } \\
\text { (calendar year) } \\
\text { years BP (yr) }\end{array}$ & $2 \sigma$ \\
\hline NYSF-1 & SNU 99-137 & $1550 \pm 90$ & 1314 (A.D. 536) & A.D. 261-660 \\
NYSF-2 & SNU 99-138 & $1930 \pm 90$ & 1875 (A.D. 75) & B.C. 163-A.D. 321 \\
NYSF-3 & SNU 99-116 & $2410 \pm 90$ & 2359 (B.C. 409) & B.C. 796-B.C. 233 \\
NYSF-4 & SNU 99-115 & $3060 \pm 80$ & 3298 (B.C. 1348) & B.C. 1504-B.C. 1050 \\
NYSF-5 & SNU 99-136 & $6250 \pm 150$ & 7182 (B.C. 5232) & B.C. 5482-B.C. 4801 \\
NYSF-6 & SNU 99-135 & $9870 \pm 340$ & 11230 (B.C. 9280) & B.C. 10845-B.C. 8323 \\
NYSF-7 & SNU 99-118 & $25900 \pm 730$ & NA & - \\
NYSF-8 & SNU 99-133 & $36600 \pm 780$ & NA & - \\
NYSF-9 & SNU 99-134 & $39400 \pm 570$ & NA & - \\
\hline
\end{tabular}

* NA: not applicable, calibrated data set only extends back to 24900 years BP (Stuiver et al., 1998). 


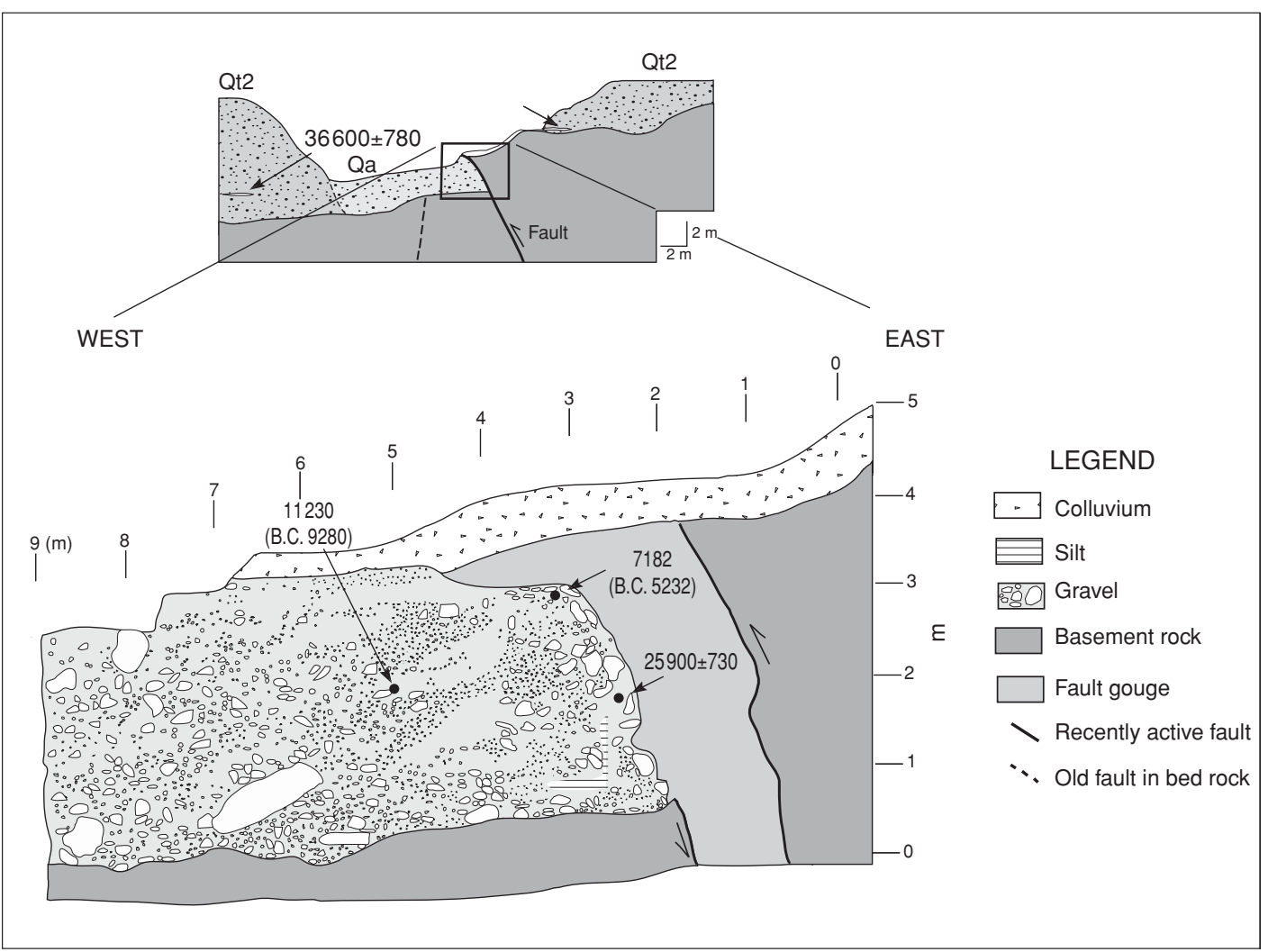

Fig. 4. Log of the northern wall across the YSF at site A in fig. 3.

deposits on both sides of the fault has AMS radiocarbon dates of $36600 \pm 780$ (SNU 99133) years BP and $39400 \pm 570$ (SNU 99-134) years BP, but these data cannot be calibrated because the calibration of the data extend only back to 24900 years BP (Stuiver et al., 1998).

A trench at site $B$, which was about $10 \mathrm{~m}$ south from site A, exposed gravelly alluvium covered by humic, silty sediments (fig. 5). The gravel deposits and humic silt were displaced by reverse faulting. The fault plane is steep in bedrock and becomes less steep upward to the west. Calibrated radiocarbon dating on organic material in the humic layer was dated at 1314 (A.D. 536) (SNU 99-137) years BP, 1875 (A.D. 75) (SNU 99-138) years BP, 2359 (B.C. 409) (SNU 99-116) years BP and 3298 (B.C. 1348)
(SNU 99-115) years BP from the upper to the lower layer, as shown in table I. The humic silt and gravel are vertically displaced about $50 \mathrm{~cm}$ down to the west. The four radiocarbon ages from the humic silt suggest that deposition of this unit began before about 2400 years BP and ended after 1314 years BP. However, the humic material in this silt was from samples that were buried only about $0.75-1.25 \mathrm{~m}$ below the surface. At such shallow depths in a humid climate such as Southeastern Korea, it is possible that some of the carbon in these samples could be from younger sources such as soluble humic acids. If these samples are contaminated by younger carbon, then the apparent age of this deposit could be too young. If the samples are not contaminated, then the radio- 


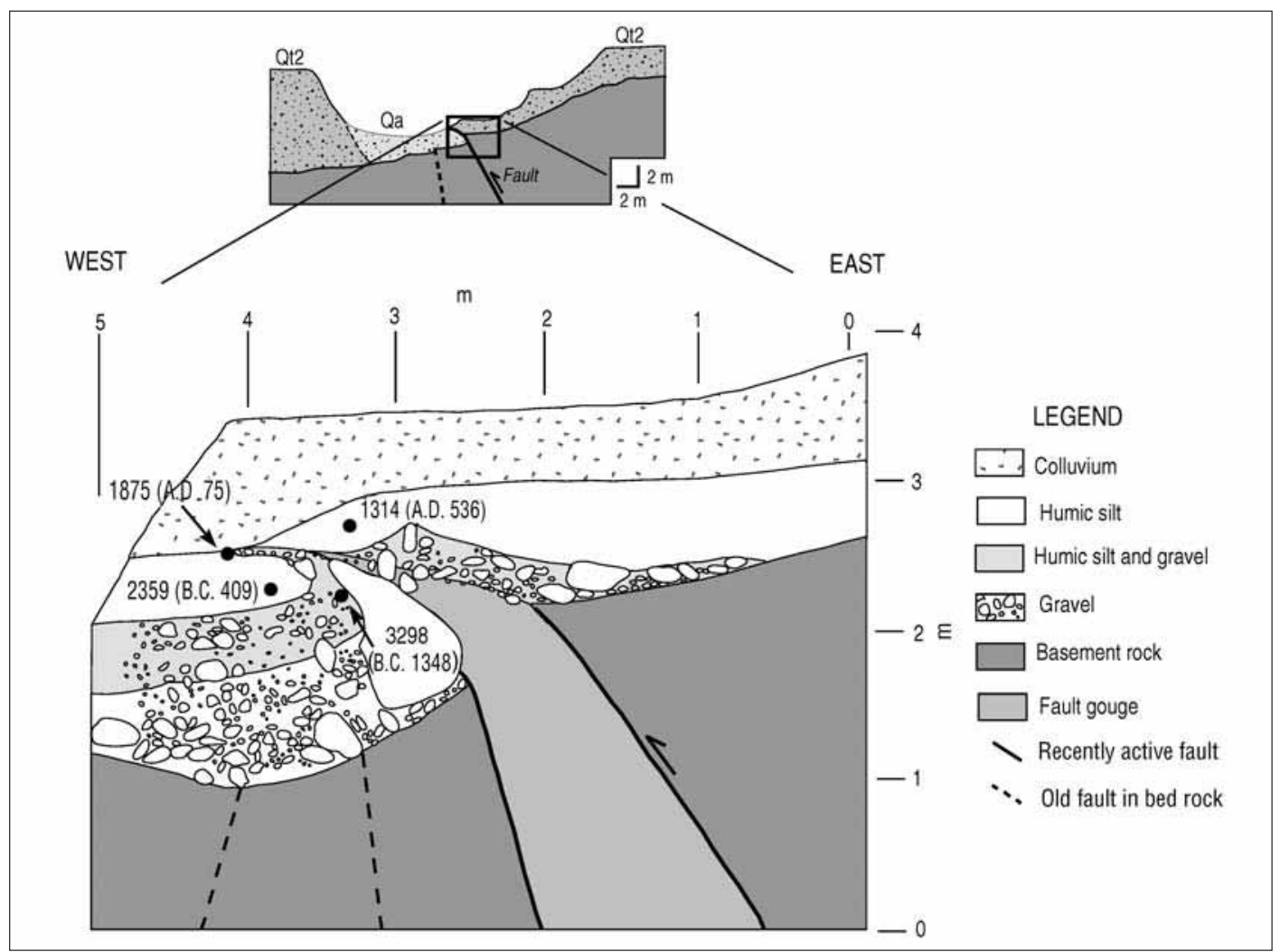

Fig. 5. Log of the northern wall across the YSF at site B in fig. 3.

carbon ages indicate that the silt was faulted less than 1314 (A.D. 536) years BP, which is the maximum age of the most recent event at this site.

\subsection{Southern part of the YSF (Ts in fig. 2)}

In the Eonyang to Tongdo-sa area on the southern part of the YSF, fluvial terraces formed by eastward-flowing streams are well developed in a relatively wide (a few $\mathrm{km}$ ) fault valley (fig. 6). The terraces can be divided into four levels (Qt1, Qt2, Qt3, Qt4), as shown in fig. 6. Following geomorphologic and geological studies in the area, we excavated several trenches across the YSF in a $10 \mathrm{~km}$ long section between Eonyang to Tongdo-sa area. The trenches exposed clear fault traces and steeply dipping fault contacts between old terrace gravels and the basement rocks.

\subsubsection{Trench $\mathrm{T}_{1 \mathrm{E}}$ and $\mathrm{T}_{1 \mathrm{~W}}$}

Studies of the topography and aerial photographs show evidence of three sub-parallel fault strand between Kyodong-ri and Shinhwa-ri (fig. 6). The eastern strand has a clear scarp about $0.6 \mathrm{~km}$ long and $12 \mathrm{~m}$ high. The trench across this scarp exposed a sharp fault contact between alluvial gravel and Cretaceous rocks of Taegu Formation (fig. 7a) (Kyung et al., 1997). The fault strikes $\mathrm{N} 40^{\circ} \mathrm{E}$ and dips northwest- 


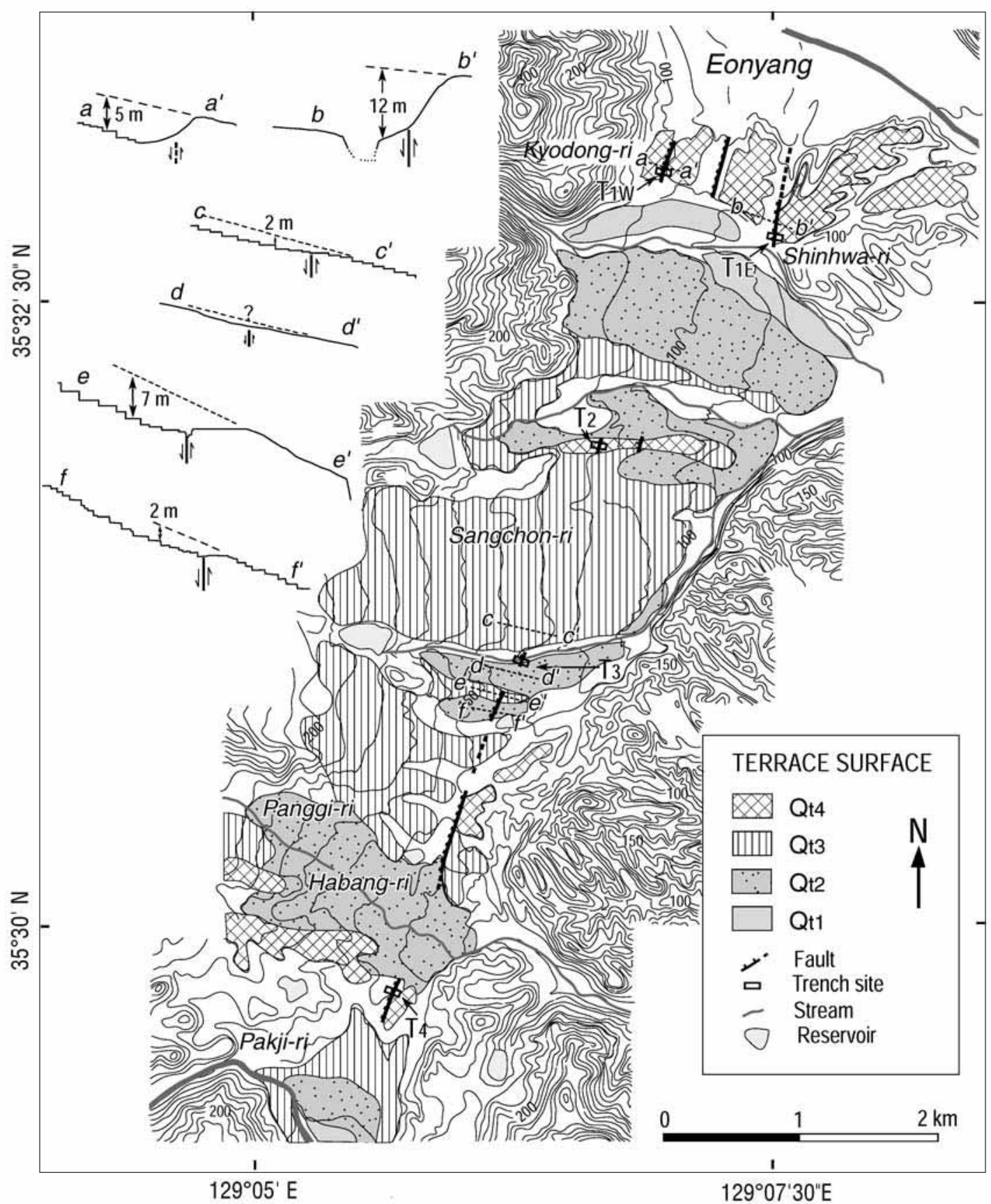

Fig. 6. Geomorphic map and topographic profiles in the southern part of Eonyang area, showing active faults and trench sites. The lines from $\mathrm{a}-\mathrm{a}^{\prime}$ to $\mathrm{f}-\mathrm{f}^{\prime}$ indicate topographic profiles. 
ward about $80^{\circ} \mathrm{N}$. The fault was covered with highly weathered reddish soil.

The total vertical displacement on the fault is about $12 \mathrm{~m}$ from the topographic profile. Although the fault has been active since deposition of Qt4 terrace gravel, its activity was probably not so high, judging from narrow cataclas- tic and gouge zone. A road sub-parallel to the central strand of the fault made it impossible to make a trench. However, the fault scarp is as high as about $8 \mathrm{~m}$ with up-to-the-east displacement (Okada et al., 1994). Several trenches were dug across the western strand of the fault, which has a $5 \mathrm{~m}$ high scarp. These trenches did

$T_{1 E}$

Northern Wall

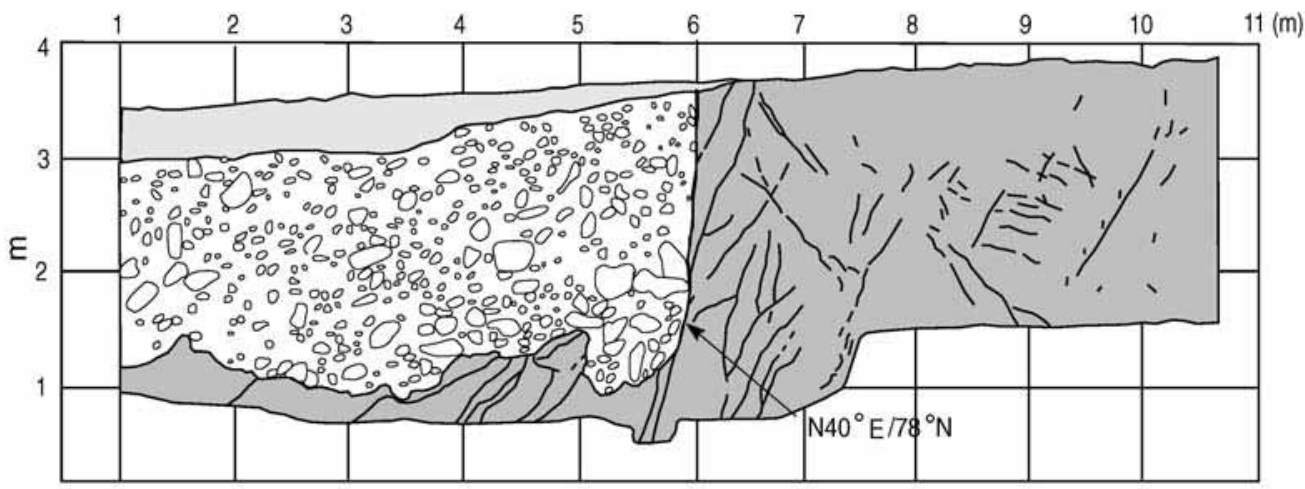

(a)

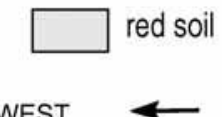

O०ᄋ weathered gravel

E\&t mudstone (Taegu Formation)

WEST

EAST

$\mathrm{T}_{2}$

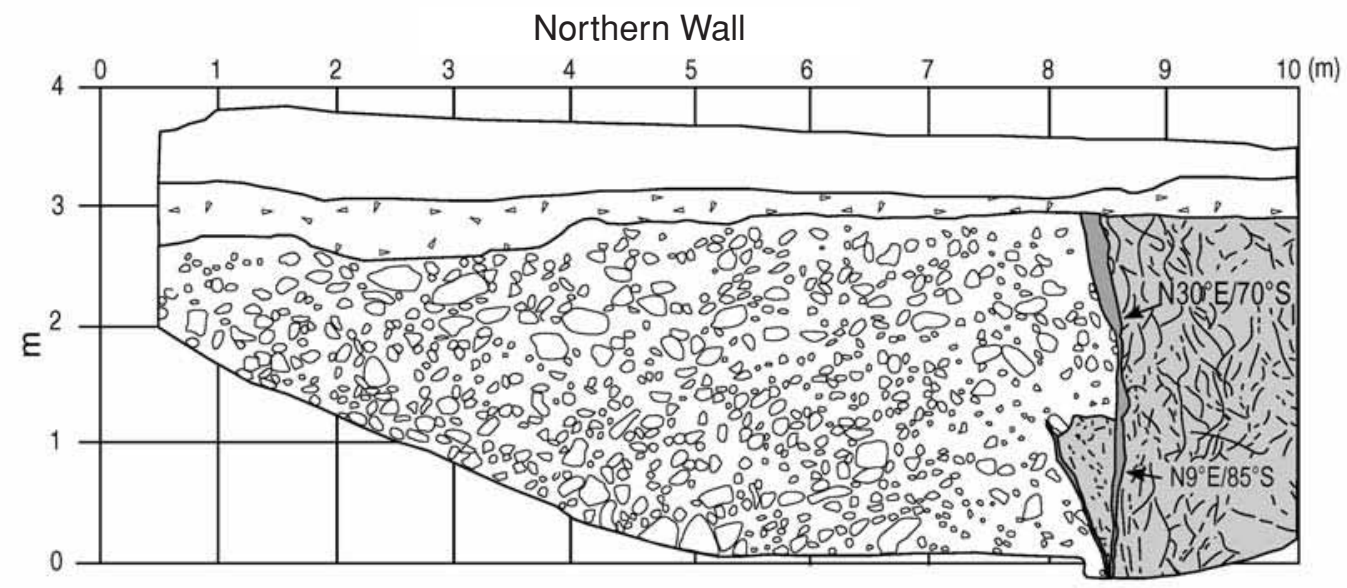

(b)

top soil

- artificial fill $0_{0}^{\circ}$ weathered gravel

fault gouge $\quad$ granite

Fig. 7a,b. Sketches of the northern wall across the YSF at site $T_{1 E}$ (a) and $T_{2}$ (b) in fig. 6. 
not expose a clear fault contact, but rather surficial reddish soil and highly weathered gravels were gently warped in to a westward-dipping monocline that formed after deposition of the Qt4 terrace gravels (Kyung et al., 1999b).

The total vertical displacement on all three strands of the fault in this area is about $25 \mathrm{~m}$.

\subsubsection{Trench $\mathrm{T}_{2}$}

South of trench $\mathrm{T}_{1}$, we identified two Quaternary fault splays in Qt4 terrace deposits that form a subtle monoclinal scarp (fig. 6). The eastern strand seems to be the main YSF and has a clear scarp and a zone of shattered rock that is tens of meters wide with a prominent fault gouge. Although the ground surface is modified, it shows vertical displacement of about $10 \mathrm{~m}$ on the fault. A highway close to the eastern strand made it impossible to trench here. So we excavated trench $\mathrm{T}_{2}$ across the western strand. On this strand, the surface still has an eastside-up scarp that has a few meters of relief even though the surface has been modified artificially.

This subsidiary strand is parallel to and about $300 \mathrm{~m}$ west of the eastern fault. In the trench, the fault dipped $70-85^{\circ} \mathrm{E}$ and had a strike of N20$30^{\circ} \mathrm{E}$. It defines the contacts between gravel of Qt4 deposits and granitic basement rock (fig. 7b) (Kyung et al., 1999a). The fault is marked by a zone of clay fault gouge that is as wide as $20 \mathrm{~cm}$ and a cataclastic zone of about $1 \mathrm{~m}$ wide.

Striations on the fault plunge $20-30^{\circ} \mathrm{N}$. Elongate gravel clasts near the fault are rotated parallel to the fault plane, and fault breccia in the gouge zone is elongated in the strike direction of fault. The en échelon arrangement of fault clay in the gouge zone indicates that recent fault movement has been predominantly rightlateral. The total amount of vertical displacement at this site is estimated to be about $10 \mathrm{~m}$ based on the offset of a gravel layer found in a drill hole. Thermoluminescence dating of the fault gouge suggests that the most recent movement on the fault is younger than about $100 \mathrm{ka}$ (Kyung et al., 1999a). But we could not find datable material in the terrace gravel to farther constrain the age of the faulting. The total ver- tical displacement on these two strands of the fault in this area is more than $20 \mathrm{~m}$.

\subsubsection{Trench $\mathrm{T}_{3}$}

South of trench 2, we excavated a trench across the fault where it crosses Qt1 terrace deposits (Qt1), which are present only adjacent to the Sangcheon stream. The fault in this trench strikes $\mathrm{N} 25^{\circ} \mathrm{E}$ and dips $80^{\circ} \mathrm{SE}$. It separates highly weathered gravels (probably Qt4 alluvium) from Cretaceous granitic rock (fig. 8a). In the trench, the faulted Qt4 gravel is buried by about 1 $\mathrm{m}$ of unweathered gravel, which extends across the fault zone and is not displaced. Based on its unweathered character, this gravel is thought to be Holocene in age, but we could not find datable materials in this deposit. The topograhic profile does not indicate a meaningful deformation across the fault strike. The stratigraphic relations in this trench show that the weathered gravel of probable Late Quaternary age is faulted, but younger Holocene (?) gravel is not faulted.

The zone of fault gouge in this trench is as wide as $20 \mathrm{~cm}$ and the zone of cataclastic rock is several meters wide. Stereographic projection of the long axes of elongate gravel clasts adjacent to the fault are oriented subhorizontally (angle of $0-30^{\circ}$ ), which is subparallel to striations in the fault gouge. These observations indicate that the predominant sense of motion on the fault has been right-lateral with a minor component of up-to-the-east reverse slip.

\subsubsection{Trench $\mathrm{T}_{4}$}

At site $\mathrm{T}_{4}$, Qt4 gravel across the estimated fault was excavated by Okada et al. (1994). Here, the up-to-the-east vertical displacement is estimated about $12 \mathrm{~m}$ based on a topographic profile. In this trench, the fault plane separates terrace gravels and basement rocks, strikes $\mathrm{N} 25^{\circ} \mathrm{E}$, and is nearly vertical (fig. 8b). The trench exposed a shattered zone several meters wide and typical fault gouge. The attitude of clasts in the gravel and elongation of clay fabric and breccia in the gouge zone suggest mainly strike-slip movement on the fault. 


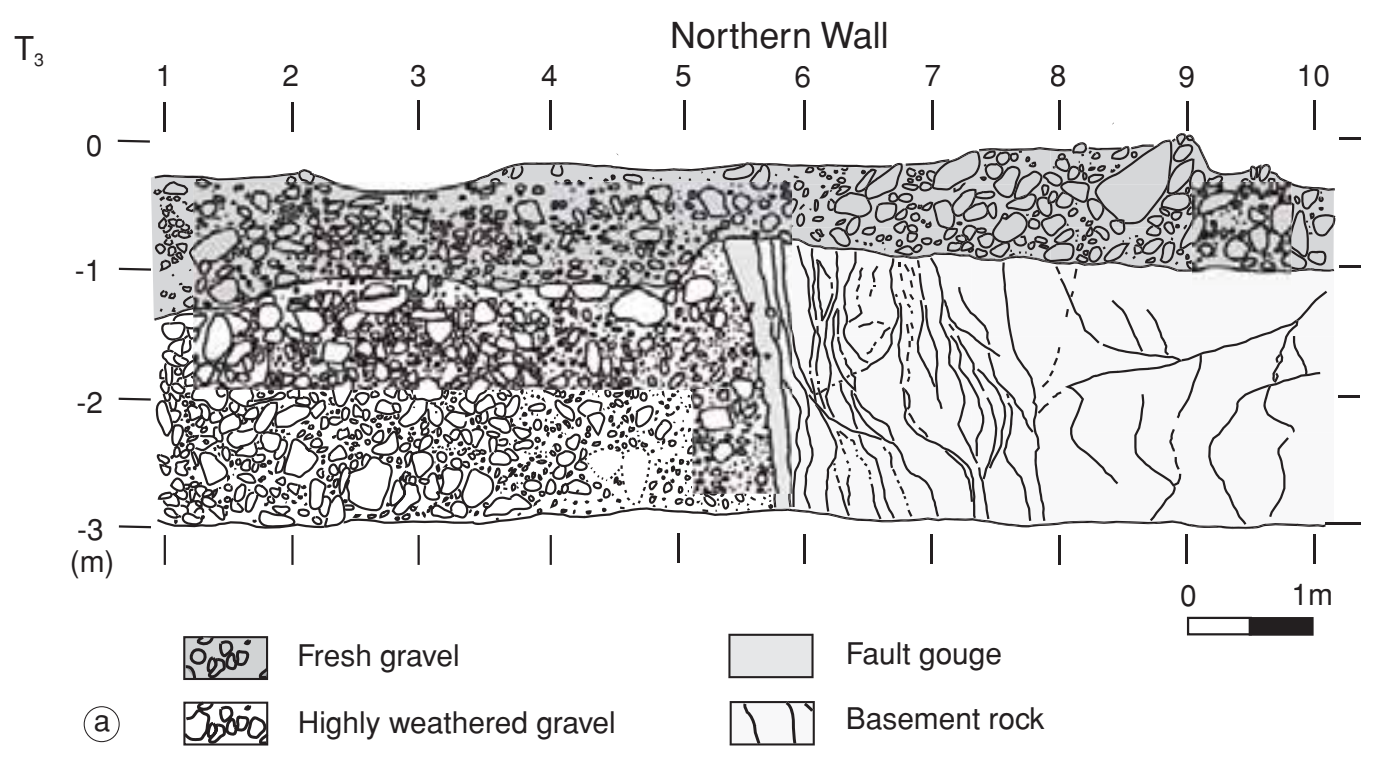

$\mathrm{T}_{4}$

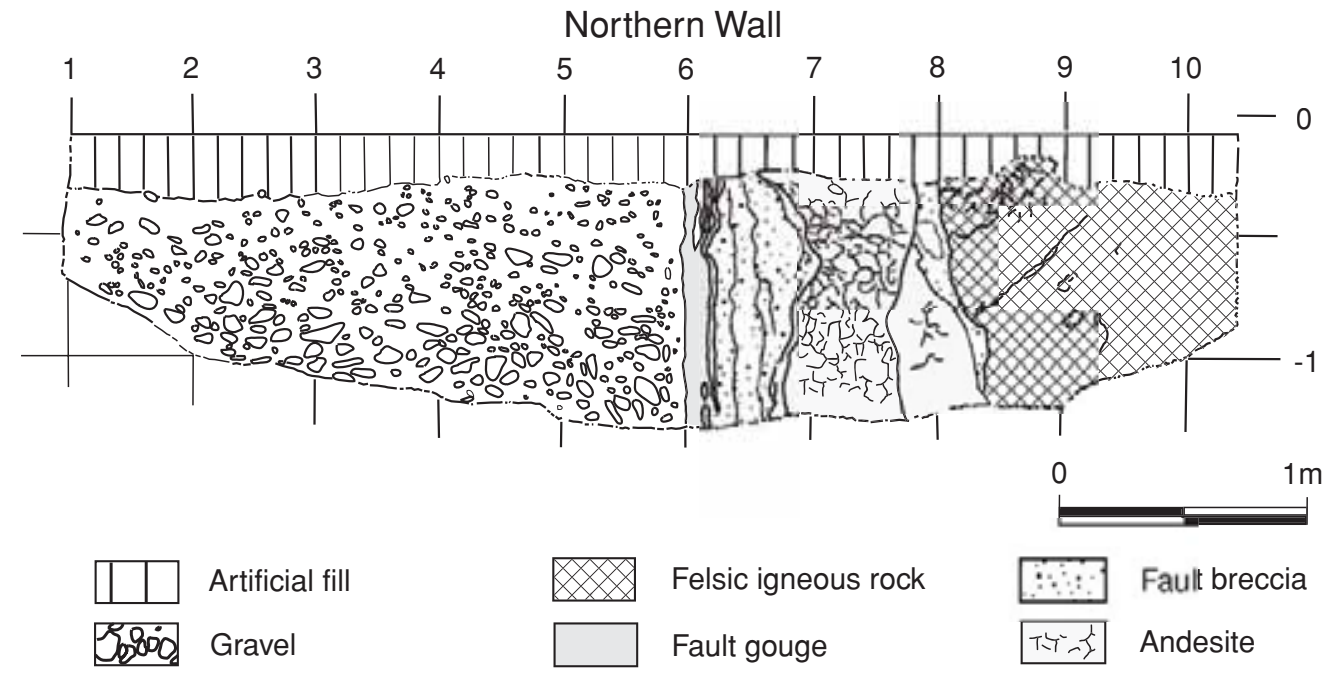

(b) $7 \int$ Light colored part within fault gouge

Fig. 8a,b. Sketches of the northern wall across the YSF at site $\mathrm{T}_{3}$ (a) and at site $\mathrm{T}_{4}$ (b) (after Okada, 1994) in fig. 6.

\section{Discussion and conclusions}

The YSF is a major structure in the southeastern Korea, and the data presented here provides new insight into Late Quaternary move- ment on the fault. The fault's linear trace, its orientation with respect to the current compressive stress field, and slip indicators in several of the trenches described here all show that recent motion on the fault is dominantly right-lateral 
strike-slip. However, the presence of prominent scarps locally along the fault and the evidence of reverse slip documented in several trenches indicates a significant component of compression on the fault. This combination of lateral and reverse faulting is common in many major strike-slip fault systems (e.g., Van Dissen and Yeats, 1991).

\subsection{Northern Yansang Fault}

The northern part of the YSF (Yugye-ri area) is characterized by several fault strands, zones of shattered bedrock tens of meters wide, and a prominent zone of fault gouge as wide as $1 \mathrm{~m}$. Eastward-plunging striations and stretching of gravel beds parallel to the fault plane indicate that recent movements have been mainly reverse slip. On terrace Qt2, reverse slip has formed a $1.5 \mathrm{~m}$ high scarp (fig. 3), and Holocene alluvial gravels are vertically offset about $0.5 \mathrm{~m}$ (fig. 5).

Based on the analysis of aerial photographs and field mapping, we recognize four terraces along this part of the YSF. The ages of individual terraces are only generally known, but estimating the age of these deposits permits us to generally estimate slip rates on the fault. The formation of major alluvial terraces is probably related to significant climate events in the Quaternary. The formation of marine terraces along the adjacent parts of the Korean coastline have been correlated with climatically related high stands of sea level, and the climatic conditions that produced these high stands may have also produced conditions favorable for the formation of alluvial terraces inland.

According to the general classification of river terrace in south Korea (Park and Kong, 2001), the high terrace surface formed during the Mindel glacial, the middle terrace surface during Riss glacial, and the lower terrace surface during the last glacial. Based on the relative height from the level of stream, the degree of weathering the gravel, and the characteristics of soil development, we can generally correlate the terraces as follows: Qt1 - last glacial $(30-10 \mathrm{ka})$, Qt2 - early last glacial (30-70 ka), Qt3 - late Riss glacial (?), Qt4 - late Mindel glacial (about 450 ka?).
On the basis of the estimated ages of the terraces, the amount of vertical displacement on those terraces, the vertical slip rate on the northern section of the fault is in the range of about $0.03-0.05 \mathrm{~mm} / \mathrm{yr}$. We do not have data that permit us to estimate the amount of Quaternary lateral slip or a lateral slip rate. In the trench at site B (fig. 5), a humic silt that has an age of about 1314 cal years BP, has been offset by recent faulting. Thus the most recent event on this part of the fault occurred about A.D. 536 (table I; $2 \sigma$ of A.D. 221-A.D 667).

Historical accounts describe several strong, damaging earthquakes that have occurred in this part of the Korean Peninsula. These accounts indicate that strong earthquakes occurred in A.D. 304, A.D. 471, A.D. 510, and A.D. 630 (fig. 1). Although the two-sigma range of ages for this sample spans the time range for many of these events, the preferred calibrated age for this event (A.D. 536) may correspond to the historical accounts of a damaging earthquake in A.D. 510 that caused fatalities.

\subsection{Southern Yangsan Fault}

Locally, the southern part (Eonyand to Tongdo-sa) of the YSF consists of at least three strands. Fault scarps of different heights on Quaternary deposits of different ages are evidence of repeated Late Quaternary movements. The trace of the fault in this area is very linear, and the fault plane exposed in trenches is high angle to vertical. Fault motion in this area is mainly rightlateral strike-slip as shown by rotated clasts adjacent to the fault zone and striations on the fault plane. A component of reverse slip has elevated the eastern side of the fault and resulted in scarps that are more than $10 \mathrm{~m}$ high on terrace Qt4.

Based on the analysis of aerial photographs and field mapping, we recognize several sets of prominent terraces along parts of the YSF. The ages of individual terraces are only generally known, but estimating the age of these deposits permits us to establish general estimates of the slip rate. Jo (1997) approximately correlated the higher terrace $(\mathrm{Qt} 4)$ to the Mindel period or Mindel/Riss interglacial period. Okada et al. (1994) estimated an age of 250-500 ka for terrace 
Qt4, about $100 \mathrm{ka}$ for terrace Qt3, and 30-60 ka for terrace Qt2. Based on the relative height of terraces above stream level, weathering of the gravel and characteristics of soil development, we can approximately correlate the terraces to the classification of river terraces (Park and Kong, 2001) as follows: Qt1 - last glacial (30-10 ka), Qt2 early last glacial (30-70 ka), Qt3 - late Riss glacial (?), Qt4 - late Mindel glacial (about $450 \mathrm{ka}$ ?).

The cumulative amount of vertical offset on Qt4 deposits is about $25 \mathrm{~m}$ on all strands, and scarps as high as 2-7 $\mathrm{m}$ are present on Qt3 deposits. Scarps as high as about $2 \mathrm{~m}$ are present on Qt2 deposits. Using the height of scarps on terraces of different ages, the vertical slip rate is in the general range of $0.02-0.07 \mathrm{~mm} / \mathrm{yr}$. The lateral slip rate may be several times larger than the vertical rate, based on the observation of near the horizontal striation for the part of the fault between Eonyand and Tongdo-sa. The most recent event on this part of the fault is thought to be pre-Holocene in age based on the evidence of unfaulted deposits of probable Holocene age (fig. 8a) and the absence of any scarps in Holocene deposits.

\section{Acknowledgements}

I thank Anthony Crone for critical advices and reviews that led to substantial improvement of this paper. I am also grateful to two anonymous referees for their constructive comments on the original manuscript. The work was supported in part by KOSEF (Korea Science and Engineering Foundation) and by KIGAM (Korea Institute of Geoscience and Mineral Resources).

\section{REFERENCES}

ChaE, B.G. and T.W. Chang (1994): Movement history of Yangsan Fault and its related fractures at ChonghaYongdok area, Korea, J. Geol. Soc. Korea, 30 (4), 379-394.

CHANG, C.J. (2001): Structural characteristics and evolution of the Yangsan Fault, Ph.D. Thesis (Kyongbuk University), pp. 259 (in Korean).

CHANG, C.J. and T.W. CHANG (1998): Movement history of the Yangsan Fault based on paleostress analysis, J. Eng. Geol., 8 (1), 161-171.

Chang, K.H., B.G. Woo, J.H. LeE, S.O. Park and A. YaO
(1990): Cretaceous and Early Cenozoic stratigraphy and history of Eastern Kyongsang Basin, S. Korea, $J$. Geol. Soc. Korea, 26, 471-487.

CHOI, H.I. and K.S. PARK (1985): Cretaceous/Neogene stratigraphic transaction and post-Kyongsang tectonic evolution along and off the southern coast, Korea, $J$. Geol. Soc. Korea, 21, 281-296.

CHOI, S.G. (1997): Development of marine and fluvial terraces and related environmental changes in the Late Quaternary along the east coast of Korea, Dissertation to the Tohoku University, pp. 200 (in Japanese).

CHOI, S.G. (2001): Tectonic movement indicated by the Late Pleistocene paleoshorelines in the eastern coast of Korea, Trans. Jpn. Geomorphol. Un., 22, (3), 265-275.

Chough, S.K., I.G. Hwang and M.Y. Choe (1990): The Miocene Doumsan fan-delta, southeast Korea: a composite fan-delta system in back-arc margin, J. Sediment. Petrol., 60, 445-455.

Chough, S.K., S.T. Kwon, J.H. ReE and D.K. Chol (2000): Tectonic and sedimentary evolution of the Korean Peninsula: a review and new view, Earth Sci. Rev., 52, 175-235.

Chun, S.S. and S.K. Chough (1992): Tectonic history of Cretaceous sedimentary basin in the southwestern Korean Peninsula and Yellow Sea, in Sedimentary Basins in the Korean Peninsula and Adjacent Seas, edited by S.K. Chough, Korean Sediment. Res. Group Spec. Publ. (Hanlimwon Publishers, Seoul, Korea), 60-76.

Jo, W.R. (1997): The geomorphic analysis of the Yangsan Fault System, J. Korean Geogr. Soc., 32, 1-14 (in Korean).

Jun, M.S. (1991): Body-wave analysis for shallow intraplate earthquakes in the Korean Peninsula and Yellow Sea, Tectonophysics, 192, 345-357.

Kıм, J.H. (1996): Mesozoic tectonics in Korea, J. Southeast Asian Earth Sci., 13, 251-265.

KIM, Y.W. and K. LEE (1988): A geoelectric study on the structure of the Yangsan Fault in the south of Kyeongju, J. Geol. Soc. Korea, 24, 47-61.

Korea InSTITUTE OF ENERGY AND RESOURCES (1981): Geological Map of Korea (scale 1:1000 000).

KYUNG, J.B. and T.W. CHANG (2001): The latest fault movement on the Northern Yangsan Fault Zone around the Yugye-ri area, southeast Korea, J. Geol. Soc. Korea, 37, 563-577

KYUNG, J.B. and C.B. IM (2001): Active fault study in the southeastern part of the Korean Peninsula, in Ten Years of Paleoseismology in the ILP: Progress and Prospects, December 2001, Kaikoura, New Zealand, Program and Abstracts, 75.

Kyung, J.B., K. Lee, A. OKada, K. Takemura, M. Watanabe, Y. SuzuKI and T. NARUSe (1997): Active fault study in the central part of the Yangsan Fault, southeastern part of Korea, in Tectonic-Evolution of Eastern Asian Continent: Geological Society of Korea 50th Anniversary Int'l Symp., edited by Y.I. LEE and J.H. KIM (Geological Society of Korea), 33-38.

Kyung, J.B., K. Lee, A. Okada, M. Watanabe, Y. Suzuki and K. TAKEMURA (1999a): Study of fault characteristics by trench in the Sangchon-ri area in the southern part of the Yangsan Fault, Southeastern Korea, J. Korean Earth Sci. Soc., 20, 101-110 (in Korean). 
KyUnG, J.B., K. LeE and A. OKADA (1999b): A paleoseismological study of the Yangsan Fault - analysis of deformed topography and trench survey, J. Korean Geophys. Soc., 2, 155-168 (in Korean).

LEE, D.S. (1987): Geology of Korea (Geological Society of Korea, Kyohaksa, Seoul), pp. 514

LEe, K. (1998): Historical earthquake data of Korea, $J$. Korean Geophys. Soc., 1, 3-22.

Maruyama, S., Y. Isozaki, G. Kimura and M. TerabaYASHI (1997): Paleogeographic maps of the Japanese Islands: plate tectonic synthesis from $750 \mathrm{Ma}$ to the present, The Island Arc, 6, 121-142.

Okada, A., M. Watanabe, H. Sato, M.S. Jun, W.R. Jo, S.K. Kim, J.S. JeON, H.C. CHI and K. Oike (1994): Active fault topography and trench survey in the central part of the Yangsan Fault, southeast Korea, $J$. Geogr. 103, 111-126 (in Japanese).

Okada, A., K. Takemura, M. Watanabe, Y. Suzuki and J.B. KyUnG (2001): Trench excavation surveys across the Yangsan and Ulsan active fault systems in the southeastern part of Korean Peninsula, Transactions, Jpn. Geomorphol. Un., 22-3, 287-306.

PARK, Y.A. and W.S. KONG (2001): The Ouaternary Environment of Korea (Seoul National University Press), pp. 564 (in Korean).

OH, G.H. (1981): Marine terraces and their tectonic deformation on the coast of the southern part of the Korean
Peninsula, Bull. Dep. Geogr. Univ. Tokyo, 13, 1-61. OH, G.H. and S.G. CHOI (2001): Marine terraces of Korea, in The Quaternary Environment of Korea, edited by Y.A. PARK and W.S. KONG (Seoul National University Press), 159-191 (in Korean).

ReE, J.H., M. Cho, S.T. Kwon and E. NaKamura (1996): Possible eastward extension of Chinese collision belt in South Korea: the Imjingang belt, Geology, 24, 10711074.

REEDman, A.J. and S.H. Um (1975): The Geology of Korea (Geology and Mining Institute of Korea), pp. 139.

Stuiver, M., P.J. Reimer, E. BARD, J.W. BECK, G.S. BurR, K.A. Hughen, B. Kromer, F.G. McCormac, J. Plicht and M. SPURK (1998): INTCAL98 Radiocarbon age calibration 24000-0 cal BP, Radiocarbon, 40, 1041-1083.

VAn Dissen, R. and R.S. Yeats (1991): Hope Fault, Jordan thrust, and uplift of the seaward Kaikoura range, New Zealand, Geology, 19, 393-396.

Yoon, S. and J.Y. KIM (1990): Tectonic history of the Yangsan Fault, southwestern part of the Korean Peninsula, in Pacific Neogene Events-Their Timing, Nature and Interrelationship, edited by R. TsucHI (University of Tokyo Press), 151-160.

Yoon, S.H. and S.K. Chough (1995): Regional strike-slip in the eastern continental margin of Korea and its tectonic implications for the evolution of Ulleung Basin, East Sea (Sea of Japan), Geol. Soc. Am. Bull., 107, 83-97. 